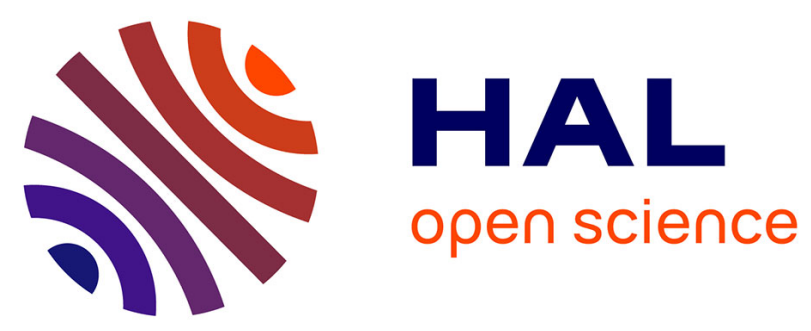

\title{
Northern Puna Plateau-scale survey of Li brine-type deposits in the Andes of NW Argentina
}

R. Lucrecia López Steinmetz, Stefano Salvi, M. Gabriela García, Didier

Béziat, Gabriela Franco, Ornela Constantini, Francisco Córdoba, Pablo Caffe

\section{- To cite this version:}

R. Lucrecia López Steinmetz, Stefano Salvi, M. Gabriela García, Didier Béziat, Gabriela Franco, et al.. Northern Puna Plateau-scale survey of Li brine-type deposits in the Andes of NW Argentina. Journal of Geochemical Exploration, 2018, 190 (2), pp.26-38. 10.1016/j.gexplo.2018.02.013 . hal-02363093

\section{HAL Id: hal-02363093 https://hal.science/hal-02363093}

Submitted on 6 Nov 2020

HAL is a multi-disciplinary open access archive for the deposit and dissemination of scientific research documents, whether they are published or not. The documents may come from teaching and research institutions in France or abroad, or from public or private research centers.
L'archive ouverte pluridisciplinaire HAL, est destinée au dépôt et à la diffusion de documents scientifiques de niveau recherche, publiés ou non, émanant des établissements d'enseignement et de recherche français ou étrangers, des laboratoires publics ou privés. 
3

\title{
Northern Puna Plateau-scale survey of Li brine-type deposits in the Andes of NW
}

\section{Argentina}

\begin{abstract}
R. Lucrecia López Steinmetz ${ }^{1,2 *}$, Stefano Salvi ${ }^{3}$, M. Gabriela García ${ }^{4}$, Didier Beziat ${ }^{3}$, Gabriela Franco ${ }^{5}$,
\end{abstract} Ornela Constantini ${ }^{5}$, Francisco E. Córdoba ${ }^{5,6}$, Pablo J. Caffe ${ }^{5,6}$

${ }^{1}$ Instituto de Geología y Minería, Universidad Nacional de Jujuy, Av. Bolivia 1661, S.S. de Jujuy 4600, Argentina

${ }^{2}$ CIT Jujuy CONICET, Universidad Nacional de Jujuy - CONICET, S.S. de Jujuy 4600, Argentina

${ }^{3}$ Université de Toulouse, CNRS, GET, IRD, OMP, 14 Av. Edouard Belin, Toulouse 31400, France

${ }^{4}$ CICTERRA-CONICET-Universidad Nacional de Córdoba, Córdoba 5016, Argentina

${ }^{5}$ Instituto de Ecorregiones Andinas (INECOA), Universidad Nacional de Jujuy - CONICET, S.S. de Jujuy 4600, Argentina

${ }^{6}$ Facultad de Ingeniería, Universidad Nacional de Jujuy, Argentina

* corresponding author: lucrecialopezsteinmetz@hotmail.com

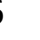

\begin{abstract}
Salars of the Andean Plateau in the Central Andes are the largest lithium deposits on Earth. The most notorious are the Chilean Salar de Atacama, and Uyuni in the Bolivian Altiplano. Despite the relevance of the region concerning the lithium resources, there is still scarce scientific literature on the hydrochemistry of lithium deposits in the Argentine portion of the Andean Plateau. In this article we present new hydrochemical data from the first regional-scale reconnaissance exploration of the four major salars in the northernmost Argentine Andes. Data revealed that brines in the studied salars are characterized by mean $\mathrm{Li}^{+}$concentrations ranging between 82 and $1,014 \mathrm{mg} \mathrm{L}^{-1}$, and mean Li:Mg ratios from 0.92 to 0.54 . The size of the study salars becomes a potential limitation for the whole Li resources in comparison with the giant Atacama and Uyuni. Nonetheless, when considering the Li grade and the Li:Mg ratio of brines, the Northern Puna salars turn out to be very remarkable lithium prospects. Data emerged from this survey represent a valuable tool for: 1) private investment projects by defining Li mining targets, 2) for the administration of natural resources and the definition of the State's politics, and 3) for scientific purposes, especially in investigations meant to better understand the processes involved in the formation of Li brine deposits, salars, and endorheic basins.
\end{abstract}

Keywords: lithium, salars, Central Andes, Altiplano-Puna Plateau, hydrochemistry 
Introduction

Salars of the Central Andes are the largest lithium deposits on Earth (Warren 2010; Houston et al. 2011;

Kesler et al. 2012; Munk et al. 2016). Particularly, the largest global resources concentrate in numerous internally drained basins of Chile, Bolivia and Argentina, where the lithium (Li) extraction has already become an important source of income in these South American countries. The Andean salars of Uyuni in Bolivia and Atacama in Chile (Fig. 1) contain the most important known Li resources in the world (Moraga et al. 1974; Gruber and Medina 2010; Mohr et al. 2010; Kunasz 2006; Kesler et al. 2012; Munk et al. 2016).

Uyuni is a spectacularly giant salar and with a surface of more than $10,500 \mathrm{~km}^{2}$ it is the largest salt pan of the Andes and on Earth (Risacher and Fritz 1991; Kesler et al. 2012). This salt pan is located in the Altiplano at 3,663 m a.s.1. (Fig. 1). The mean Li content in the near-surface brines of Uyuni ranges from 316 to $602 \mathrm{mg} \mathrm{L}^{-1}$ and the Li concentration pattern across the salar increases towards the south (Ericksen et al. 1976; Ericksen et al. 1977; Rettig et al. 1980; Risacher and Fritz 1991; Schmidt 2010). The estimated Li resources of Uyuni are over 10.2 Mt, which represent $\sim 12$ times the estimated resources of Greenbushes in Australia, the world famous Li pegmatite deposit (Kesler et al. 2012).

Although Uyuni is probably the most important Li resources worldwide, this salar is not in production yet. Much of the Li being produced globally at present is obtained from the Salar de Atacama. With estimated resources reaching 6.3 Mt, Atacama is thus the most important Li mine in the world (Moraga et al. 1974; Ide and Kunasz 1989; Kunasz 2006; Lowenstein and Risacher 2009; Gruber and Medina 2010; Mohr et al. 2010; Kesler et al. 2012; COCHILCO 2013).

The Salar de Atacama (Fig. 1) is a 3,000 $\mathrm{km}^{2}$ salt pan located at 2,300 m a.s.l., whose halite nucleus spreads 1,100 km² and $\sim 1,000 \mathrm{~m}$ depth (Moraga et al. 1974; Stoertz and Ericksen 1974; Bevacqua 1992; Alonso and Risacher 1996; Carmona et al. 2000; Boschetti et al. 2007; Jordan et al. 2007; Boutt et al. 2016; Corenthal et al. 2016). The average Li concentration of Atacama is $\sim 1,400 \mathrm{mg} \mathrm{L}^{-1}$, ranging between 1,000 and $6,400 \mathrm{mg} \mathrm{L}^{-1}$ (Moraga et al. 1974; Ide and Kunasz 1989; Kunasz 2006), representing the maximum Li concentration in a brine-type deposit reported to date worldwide. The Li concentration pattern across the Salar de Atacama is well known: five concentric Li grade zones were defined, with the higher Li grade zone located in the southern part of the salar (Ide and Kunasz 1989).

61 In the Argentine Puna region, in the southernmost part of the Andean Plateau (Fig. 1), there are also some remarkable Li prospects. The most prominent is the Salar de Hombre Muerto (Fig. 1), which became the 
first Li mine operating in Argentina since the 90's (Kesler et al. 2012; Fornillo et al. 2015). Hombre Muerto comprises a $300 \mathrm{~km}^{2}$ salt pan placed at 3,970 m a.s.l., with estimated $\mathrm{Li}$ resources of $0.8 \mathrm{Mt}$, and mean $\mathrm{Li}$ contents of $\sim 520 \mathrm{mg} \mathrm{L}^{-1}$; the concentration pattern across the salar increases towards the south (Garrett 2004; Kesler et al. 2012; Godfrey et al. 2013).

As mentioned, the Li resources of salars in the Chilean Desierto de Atacama and the Bolivian Altiplano are largely known (Ericksen et al. 1977; Ide and Kunasz 1989; Risacher and Fritz 1991; Alonso and Risacher 1996; Risacher et al. 1999; Carmona et al. 2000; Risacher et al. 2003; Kunasz 2006; Risacher and Fritz 2009). On the contrary, and despite the relevance of this strategic mineral resource and the outstanding prospect of the Andean salars, there are still scarce scientific works on the hydrochemistry of Li deposits in the Argentinean Puna (Fig. 1). This region is becoming an increasing focus of exploration activity. Most of the available information of Puna salars is based on reports provided by mining companies and regional data reported in a number of scientific papers (Yaksic and Tilton 2009; Gruber and Medina 2010; King 2010; Houston et al. 2011; Fornillo et al. 2015; Munk et al. 2016). On the contrary, local works aiming to characterize the hydrochemistry of Li deposits in this Andean region are restricted to the Salar de Hombre Muerto (Godfrey et al. 2013; Fig. 1) and the Salar de Centenario-Ratones (Orberger et al. 2015) in the Southern Puna (Alonso et al. 1984), and the Guayatayoc playa lake in the Northern Puna (López Steinmetz 2017; Fig. 2). There are still many other salars in the Puna region that are promising Li prospects, and that - to date - were not object of scientific surveys, even of a reconnaissance nature. For instance, in the Northern Puna little is known about the hydrochemistry of the Cauchari and the Salinas Grandes salt pans, whereas the Salar de Jama remains completely unexplored (Fig. 2). In this work we report the results of a regional Li exploration campaign covering an area of $9,000 \mathrm{~km}^{2}$ in the endorheic Northern Puna (Fig. 2) that includes the four major salars which represent promising Li prospects. The major chemical composition and Li content of brine samples collected from the Salar de Jama, Olaroz, Cauchari and Salinas Grandes are analysed in order to contribute to the knowledge of the Andean salars hydrochemistry from a regional perspective. This research is the first scientific report on Li resources in the Northern Puna Plateau, and, along with the information previously reported by López Steinmetz (2017), completes the first broad survey of Li-bearing salars on the northern Argentine Plateau. We finally propose to discuss the Li resource perspectives of the Northern Puna region in the context of the most notorious Andean prospects.

\section{The study area}



Jama is the smallest one, and is located on the Argentina-Chile border, at the foothills of the Jama volcano. Eastward, the Salar de Olaroz and Cauchari occupy the same north-south elongate orographic depression, superficially detached one from the other by prograding alluvial fans (the composite Archibarca alluvial cone). Finally, the Salinas Grandes covers the easternmost reaches of the lower Northern Puna, limiting to the north with the Guayatayoc salar basin.

There is an altitudinal gradient across the Northern Puna, which determines that western salars are placed at higher altitude than those located to east (Fig. 2). These four salars extend between $23^{\circ}-24^{\circ} \mathrm{S}$. Northward, the endorheic basins of the Northern Puna are characterized by the presence of lakes that only occasionally dry out (e.g., Laguna de Pozuelos, McGlue et al. 2012; Laguna de Pululos, Lupo et al. 2006). Orographic depressions that host salars are defined by north-south trending ranges formed during Andean thrusting events. These ranges expose the basement, which consist of Lower to Middle Ordovician (Santa Victoria Group, Turner 1960 a, b) and Precambrian - Eocambrian (Puncoviscana Formation, Turner 1960 a, b) metasedimentary rocks in the Puna Plateau and the Eastern Cordillera, respectively. The latter unit, together with Upper Cambrian sedimentary rocks (Meson Group, Turner 1960 a, b) are only present along the eastern border of the study area (Fig. 2). Middle to Upper Ordovician peraluminous, plutonic complexes and Jurassic to Cretaceous alkaline granites (Méndez et al. 1973; Zappettini 1989; Coira et al. 1999; Cristiani et al. 1999; Kirschbaum et al. 2006) are widely distributed in ranges along the western side of the Salinas Grandes and, in a lesser extent, along the eastern margin of the Salar de Olaroz (Fig. 2). Cretaceous to Paleocene rift-related sedimentary rocks (Salta Group, Turner 1959) frequently crop out overlain by Upper Eocene to Upper Miocene synorogenic deposits (Turner 1972; Schwab 1973; Schwab and Lippolt 1974; Arias and Viera 1982; Seggiaro 2013). These units are widespread in the southern portions of the Tanque and Pircas ranges, and in the Alta range, in the southern border of the Salinas Grandes. Paleogene to Lower Miocene continental red beds ( $\log \log$, Vizcachera and Peña Colorada formations; see Coira et al. 2004; Seggiaro 2013; and references therein) were deposited afterwards in a broken foreland environment (e.g., del Papa et al. 2013), Fluviatile to lacustrine deposits intercalated with air fall tuffs and pyroclastic flow deposits (Tiomayo, Trincheras and Pastos Chicos formations) characterise the Middle to Upper Miocene (16 to $10 \mathrm{Ma}$ ) sedimentary/volcaniclastic record (Schwab and Lippolt 1974; Coira et al. 2004).

121 Towards the Upper Miocene-Pliocene transition similar sedimentary sequences (Loma Blanca/Sijes Formation; 

alluvial fan deposits extend between the foot of the mountains and the flat areas, which are covered by finegrained sediments and salt pans. Salar mining in the Northern Puna was traditionally related to the extraction of halite and ulexite from these salt pans, while Li mining started recently (2014), the Salar de Olaroz and Cauchari being the only active brine prospects (Fornillo et al. 2015).

The environmental conditions that prevail in these high-altitude endorheic basins are typically extreme, with low effective precipitation and wide temperature fluctuations. Thus, rainfall is markedly seasonal, with $\sim 70 \%$ of the yearly total falling during the austral summer (December-March), while the dry season spans over the rest of the year. High rates of evaporation and low annual rainfall, averaging $150-400 \mathrm{~mm}$ and increasing from SW to NE, are responsible for a negative water balance. As a consequence, fluvial systems mainly consist of ephemeral streams. Despite most tributaries infiltrate before reaching the salars, some major fluvial collectors feed the systems over the year (Fig. 2). In addition, groundwater discharge probably represents an important source of water to the salar systems (Peralta Arnold et al. 2017).

\section{Methods}

For the Li reconnaissance exploration and hydrochemical assessment of the Northern Puna salars, residual brines were sampled across the Salar de Jama (JA), Olaroz (OL), Cauchari (CA) and Salinas Grandes (SG, Fig. 3). The detailed location of samples is presented in Table A of the electronic supplementary material. Brine samples were collected and analysed during the austral spring 2010 (from September until December). Samples were collected at 40 to $90 \mathrm{~cm}$ depth in pits dug in salars, except for samples JA10, OL10, CA1, CA2 and SG10 that were collected from brine pools. Samples were stored in pre-cleaned polyethylene bottles and preserved refrigerated during transport.

Brine samples were analysed at the Agua de los Andes S. A. laboratory. Analytical results are summarized in Table 1. Physicochemical parameters such as $\mathrm{pH}$ and electrical conductivity were determined with a Hanna HI2314 multi-range conductivity meter. The major ion composition was determined following standard recommendations (Clesceri et al. 1998). Calcium $\left(\mathrm{Ca}^{2+}\right)$ was determined by titration using a $0.01 \mathrm{M}$ EDTA solution, while magnesium $\left(\mathrm{Mg}^{2+}\right)$ was calculated as the difference between total hardness and calcium concentration. Chloride $\left(\mathrm{Cl}^{-}\right)$was determined by titration using the argentometric method. Sulphate $\left(\mathrm{SO}_{4}{ }^{2-}\right)$ was 
precipitated in an acetic acid medium with $\mathrm{BaCl}_{2}$ and its concentration was determined by turbidimetry. Bicarbonate and carbonate $\left(\mathrm{HCO}_{3}{ }^{-}\right.$and $\left.\mathrm{CO}_{3}{ }^{2-}\right)$ were determined by titration using a $0.01 \mathrm{~N}$ sulfuric acid solution and methyl-orange and phenolphthalein were used as end-point indicators, respectively. Boron (B) was determined by colorimetry using carmine reactive. Sodium $\left(\mathrm{Na}^{+}\right)$, potassium $\left(\mathrm{K}^{+}\right)$and lithium $\left(\mathrm{Li}^{+}\right)$were determined by Atomic Emission Spectroscopy. Ion balances were typically lower than 5\% in all cases. Saturation index (SI) was calculated by using the PHREEQC 3.3.8 public domain and simulation program of the USGS, and employing the Pitzer database.

\section{Li-bearing salars of the Northern Puna}

\section{The Salar de Jama}

Jama is a north-south elongated salt pan located at 4,080 $\mathrm{m}$ a.s.l. The salar surface is $25 \mathrm{~km}^{2}$, spreading between $67^{\circ} 02^{\prime}-67^{\circ} 04^{\prime} \mathrm{W}$ and $23^{\circ} 15^{\prime}-23^{\circ} 21^{\prime} \mathrm{S}$ (Fig. 3A). Main tributaries are the Coruro, Lina and Pircas Rivers. Local lithology involves the Ordovician metasedimentary basement and Miocene - Pliocene ignimbrites (the Mucar, Atana and Toconao ignimbrites), dacite lavas as well as small mafic andesite volcanic centres (the Jama and Archibarca volcanoes). The salar overlies Quaternary alluvial deposits that interdigitate with a muddy salt shoreline along the south-eastern border of the salar.

Jama's brines are alkaline, with pH values ranging between 8.2 and 8.8 (Table 1), and moderately saline, with electrical conductivity values ranging between 12.33 and $183.63 \mathrm{mS} \mathrm{cm}^{-1}$ (Table 1). According to their major chemical composition, brines are of the $\mathrm{Na} / \mathrm{Cl}^{-}-\mathrm{SO}_{4}{ }^{2-}$ type, with relatively abundant $\mathrm{Ca}^{2+}$ and $\mathrm{K}^{+}$ (Fig. 4).

When the mean ionic concentration of Jama's brines is compared with those of the other Northern Puna salars, the Jama brines result the most dilute (Fig. 5). The Na:Cl ratios in the Jama brines are $\sim 1$ (Fig. 6A). The $\mathrm{SO}_{4}{ }^{2-}$ and $\mathrm{Ca}^{2+}$ concentration pattern characterizes by a $\mathrm{SO}_{4}{ }^{2-}>\mathrm{Ca}^{2+}$ linear trend (Fig. $6 \mathrm{~B}$ ), except for the samples JA6, JA9 and JA10 that depict much higher SO42- concentrations.

Ratios near to 1 evidence salt recycling process, including halite and anhydrite/gypsum solubilisation and precipitation. According to saturation indexes (SI), these brines are unsaturated in anhydrite (SI from -2.19 to -1.41), gypsum (SI from -1.97 to -1.11), sylvite (SI from -4.29 to -2.11 ) and halite (SI from -3.60 to -1.43 ). According to this, the excess of $\mathrm{SO}_{4}{ }^{2-}$ over $\mathrm{Ca}^{2+}$ (Fig. 6B) evidences the contribution of sulphate originated from the solubilisation of non-Ca sulphates and/or the scavenging of $\mathrm{Ca}^{2+}$ by cation exchange and/or by 
dolomite/calcite precipitation. Because brines are supersaturated with dolomite (IS from 0.33 to 1.07) and calcite (IS from 0.05 to 0.60 ) it seems that the latter should be the dominant process controlling $\mathrm{Ca}^{2+}$ concentrations in Jama's brines.

The $\mathrm{Li}^{+}$concentration in the Jama's brines ranges between 1.5 and $262 \mathrm{mg} \mathrm{L}^{-1}$, with the highest $\mathrm{Li}$ grade zone along the north-western border of the salar (Fig. 7A). The mean $\mathrm{Li}^{+}$concentration in the shallowest brines of the salar is $82 \mathrm{mg} \mathrm{L}^{-1}$ while the mean Li:Mg ratio is 0.63 (Table 2). Borate concentrations in these brines range between 236 and 3,069 $\mathrm{mg} \mathrm{L}^{-1}$; no linear correlation between $\mathrm{Li}$ and $\mathrm{B}$ has been observed, being $\mathrm{Li}<\mathrm{B}$ with the $\mathrm{Li} / \mathrm{B}$ ratio up to 0.29 (Table 1 ).

\section{The Salar de Olaroz and Cauchari}

These two salars are located in a N-S elongated basin at an average altitude of 3,903 $\mathrm{m}$ a.s.1. The Salar de Olaroz is a $130 \mathrm{~km}^{2}$ salt pan spanning between $66^{\circ} 39^{\prime}-66^{\circ} 45^{\prime} \mathrm{W}$ and $23^{\circ} 24^{\prime}-23^{\circ} 33^{\prime} \mathrm{S}$ (Fig. 3B). The northern catchment area includes numerous hydrothermal springs, where the main fluvial collector is the Rosario River that discharges into the north of the salar. The other main tributary to the salar is the Archibarca River that reaches the salt pan from the west. This river forms a huge prograding alluvial fan that dissects the Olaroz Cauchari topographic depression and acts as a barrier between the Olaroz (to the north) and the Cauchari salt pans.

The Salar the Cauchari is located at the southern part of the basin, between $23^{\circ} 39^{\prime}$ and $23^{\circ} 50^{\prime} \mathrm{S}$, covering an area of $\sim 80 \mathrm{~km}^{2}$ (Fig. 3B). The dominant lithologies in the basin are sedimentary sequences and volcanic rocks. The Tocomar River is the major fluvial collector and reaches the salar from the south (Fig. 2). The southern catchment area includes numerous hydrothermal springs.

Shallow brines in both salars are circumneutral to alkaline, with $\mathrm{pH}$ values ranging between 8.1 and 8.5 in Olaroz and from 7.2 to 9.3 in Cauchari (Table 1). The brines' major chemical composition is dominated by $\mathrm{Na} / \mathrm{Cl}^{-}$type waters (Fig. 4), with electrical conductivity values and ionic contents that are up to one order of magnitude higher than those measured in the Jama's brines (from 184.85 to $320.15 \mathrm{mS} \mathrm{cm}^{-1}$, Fig. 5B). These values represent the highest ionic concentrations measured in the Northern Puna salars.

The Na:Cl ratios are $\sim 1$ in Cauchari and $\leq 1$ in Olaroz (Figure 6A). Despite this, brines are undersaturated with halite in both the Cauchari and the Olaroz salars (SI ranging from -1.44 to -0.91). Like Jama, the concentration of $\mathrm{SO}_{4}{ }^{2-}$ is higher than $\mathrm{Ca}^{2+}$ in the Olaroz and Cauchari brines (Fig. 6B). This pattern could be the result of coupled reactions involving dissolution of gypsum/anhydrite and subsequent scavenging of $\mathrm{Ca}^{2+}$ by 
dolomite/aragonite/calcite precipitation. In agreement, saturation indexes for anhydrite and gypsum vary from 3.29 to -2.11 and -3.16 to -1.92 , respectively. However, brines are supersaturated with carbonates only in the northern Cauchari area (the SIdolomite ranges from 0.44 to 1.40 in samples CA1, CA2 and CA3, the SIaragonite is 0.24 in the CA2, and the SIcalcite varies from 0.08 to 0.38 in samples CA2 and CA3), but are undersaturated in the southern Cauchari and the entire Olaroz (SIdolomite: -1.56 to -0.16 ; SIaragonite: -1.37 to -0.07 ; SI calcite: -1.22 to -0.22 ). These values evidence thermodynamically optimum conditions for locally constrained carbonate precipitation and sulphate dissolution, leading to the concomitant existence of sulphated-rich inputs. $\mathrm{L}^{-1}$ in Cauchari. The highest Li grade zones occupy the central area of these two salars (Fig. 7B and C). The mean $\mathrm{Li}^{+}$concentration is $860 \mathrm{mg} \mathrm{L}^{-1}$ in Cauchari and $1,014 \mathrm{mg} \mathrm{L}^{-1}$ in Olaroz, the $\mathrm{Li}: \mathrm{Mg}$ ratios are 0.86 and 0.89 , respectively (Table 2). The borate concentration in these brines varies between 1,336 and $3,175 \mathrm{mg} \mathrm{L}^{-1}$ (Table 1) and do not show a linear correlation with $\mathrm{Li}$ contents, with $\mathrm{Li}<\mathrm{B}$ and the $\mathrm{Li} / \mathrm{B}$ ratio up to 0.96 in Cauchari and 0.29 in Olaroz.

The Salinas Grandes

Salinas Grandes is a large salt pan of $280 \mathrm{~km}^{2}$ placed at $3,410 \mathrm{~m}$ a.s.l. between $23^{\circ} 33^{\prime}-23^{\circ} 45^{\prime} \mathrm{S}$ and $65^{\circ} 51^{\prime}-66^{\circ} 12^{\prime} \mathrm{W}$ (Fig. 3C). This salar developed south of the Las Burras alluvial fan, which separates the Salinas Grandes salt pan from the Guayatayoc playa lake to the north. Permanent streams feeding the Salinas Grandes include the San Antonio de los Cobres and the El Moreno Rivers. The southern catchment area of the San Antonio de los Cobres River includes numerous hydrothermal springs, while the headwater area of the El Moreno basin involves seasonal periglacial processes. Muddy salt shorelines associated to the mouth of the El Moreno River are mainly developed along the south-eastern border of the salt pan. Quaternary alluvial deposits cover the low lying areas and reach the foot of mountains. The metasedimentary basement and the Cretaceous to Paleocene sedimentary sequences are the most widespread lithologies along the eastern side of the basin, while Paleozoic and Mesozoic plutonic rocks outcrop in the west-boundary ranges. slightly alkaline, with $\mathrm{pH}$ ranging from 7.1 and 8.0 (Table 1). Electrical conductivity show intermediate values compared with the remaining salars of the Northern Puna, typically ranging between 232.18 and $241.08 \mathrm{mS} \mathrm{cm}^{-1}$ (Fig. 5B). Major ionic concentrations are dominated by $\mathrm{Na}$ and $\mathrm{Cl}$ ions (Fig. 4). Interestingly, these brines show the largest variability of the ionic concentrations compared with the neighbour salars (Fig. 5). The sample SG1 is 
the most diluted (conductivity $=233.85 \mathrm{mS} \mathrm{cm}^{-1}$ ) and characterizes by the lowest $\mathrm{Ca}^{2+}$ concentration compared with the remaining samples collected from the Salinas Grandes (Fig. 5), and a Na:Cl ratio $~ 1$ (Fig. 6A). Conversely, the sample SG7 contains high $\mathrm{Mg}^{2+}$ and $\mathrm{K}^{+}$concentrations, even when compared with the other salars of the Northern Puna (Fig. 5A). The Salinas Grandes brines also show nearly equivalent proportions of $\mathrm{Ca}^{2+}, \mathrm{Mg}^{2+}$ and $\mathrm{K}^{+}$with $\mathrm{Ca}: \mathrm{Mg} \sim 1$ (Fig. 4), and typically have $\mathrm{Ca}^{2+}>\mathrm{SO}_{4}^{2-}$ (Fig. 6B). Saturation indexes indicate that brines are undersaturated in calcite, aragonite, and dolomite (SIdolomite: -2.07 and $-1.55, \mathrm{SI}_{\text {aragonite: }}-1.30$ to 1.11 and the SI calcite: -1.15 and -0.97$)$.

The equivalent concentrations of $\mathrm{Li}$ and borate through the salar are similar (Fig. 5A), with the Li:B ratio close to 1 in samples $\mathrm{SG} 4, \mathrm{SG} 6$ and $\mathrm{SG} 9$ (Li/B of $0.95,1.10$ and 0.99 , respectively), Li $>\mathrm{B}$ in samples 5,8 and 10 (from 1.17 to 1.32 ), and $\mathrm{Li}<\mathrm{B}$ in the remaining samples ( $\mathrm{SG} 1=0.07, \mathrm{SG} 2=0.67$ and $\mathrm{SG} 3=0.70)$. The concentration of borate is from 309 and up to $542 \mathrm{mg} \mathrm{L}^{-1}$, and $\mathrm{Li}^{+}$ranges between 25 and $1,018 \mathrm{mg} \mathrm{L}^{-1}$, with the highest Li grade zone located at the western margin of the salar (Fig. 7D). The mean $\mathrm{Li}^{+}$concentration is $332 \mathrm{mg}$ $\mathrm{L}^{-1}$ and the mean Li:Mg ratio is 0.54 (Table2).

\section{DISCUSSION}

The major chemical composition of the studied brines is rather constant; most samples are of the $\mathrm{Na} / \mathrm{Cl}^{-}$ type with some subordinated samples of the $\mathrm{Na} / \mathrm{Cl}^{-}-\mathrm{SO}_{4}{ }^{2-}$ type. Thus, the highly concentrated brines are typically rich in $\mathrm{Na}^{+}$and $\mathrm{Cl}^{-}$, and relatively poor in $\mathrm{Ca}^{2+}, \mathrm{Mg}^{2+}$ and $\mathrm{HCO}_{3}{ }^{-}+\mathrm{CO}_{3}{ }^{2-}$. An additional common feature in the Northern Puna brines is that $\mathrm{K}^{+}$concentrations are from 2 to 6 times higher than those of $\mathrm{Mg}^{2+}$. However, the most conspicuous feature is the high Li grades, with average concentrations from 82 to $1,014 \mathrm{mg} \mathrm{L}^{-1}$, the highest ones found in the Cauchari and Olaroz salt pans.

Hydrochemical features of the Andean salars are controlled by a number of variables acting at different scales. In a recent work, Munk et al. (2016) have defined six major features shared by most Li-rich brines deposits at a global scale: (1) arid climate; (2) closed basin containing a salar (salt crust), a salt lake, or both; (3) associated igneous and/or hydrothermal activity; (4) tectonically driven subsidence; (5) suitable Li sources; and (6) sufficient time to concentrate $\mathrm{Li}$ in the brine. However, even though all these features converge across the Puna Plateau, brines from the studied salars have an uneven distribution of Li grades. Therefore, there must be some local factors constraining the higher concentrations of Li to some particular systems. salinity (Fig. 5) of the study brines. In the four studied salars, average salinity is the highest in Olaroz and the 
lowest in Jama, while intermediate values were measured in Cauchari and Salinas Grandes. In addition to salinity, the concentration pattern $\mathrm{OL} \geq \mathrm{CA} \geq \mathrm{SG} \geq \mathrm{JA}$ is valid for $\mathrm{Mg}^{2+}, \mathrm{K}^{+}, \mathrm{Li}^{+}$and $\mathrm{BO}_{3}{ }^{3-}$ concentrations, but not for $\mathrm{Ca}^{2+}$, whose regional concentration pattern is $\mathrm{SG} \geq \mathrm{JA} \geq \mathrm{CA} \geq \mathrm{OL}$. The lower $\mathrm{Ca}^{2+}$ concentrations observed in Olaroz and Cauchari are the consequence of local geochemical processes that involve precipitation of calcite/aragonite but also of some other Ca-scavenging process such as cation exchange. The latter mechanism might occur during the interaction between Ca-rich solutions and clay minerals accumulated in the salt pan. Eugster (1970). The behaviour of trace elements such as Li and borate in the context of this chemical divide has been scarcely assessed. For example, Witherow and Lyons (2011) determined on the basis of geochemical modelling that $\mathrm{Li}$ is largely conservative in water samples of the Great Basin (USA), Saskatchewan, and the McMurdo Dry Valleys of Antarctica and, thus, its concentration is the result of long-term solute input and concentration through evaporation and/or sublimation processes. According to this, Li behaves as an incompatible element, not only during the stages of magmatic differentiation but also during weathering (Munk et al. 2016). Therefore, its concentration during brine evolution should follow an increasing trend with increasing water salinity. However, we have observed no unequivocal correlation between the Li grade of brines and conductivity nor other conservative solutes such as $\mathrm{Na}$ and $\mathrm{Cl}$. For instance, as shown in Figure 8A, the Jama and Cauchari samples have a remarkable Li/Conductivity correlation, but brines from the Salinas Grandes and Olaroz show Li concentrations that increase independently from salinity (Fig. 8A). This suggests that during the sediment-water interaction, Li ions may in some extent co-precipitate as an impurity in the minerals present in the saline crusts and efflorescens or it could be adsorbed onto clay minerals due to the capacity of $\mathrm{Li}^{+}$to be incorporated into the smectite interlayers (e.g., Zhang et al. 1998; William and Herving 2002).

The hydrothermal activity is considered as one of the most significant factors for the formation of $\mathrm{Li}$ and boron rich brines in the Central Andes (Risacher et al. 2003; Godfrey et al. 2013; López Steinmetz 2017; and references therein). Indeed, a number of authors indicated that the main sources of Li in Uyuni and the nearby salars of Coipasa and Empexa in the southern part of the Bolivian Altiplano are thermal springs associated with Quaternary rhyolitic volcanism (Shcherbakov and Dvorov 1970; Ericksen et al. 1977; Campbell 2009). Since hydrothermal activity on the region is largely related to volcanism and the formation of the plateau (i.e., Isacks 
references therein), it could be considered that this regionally pervasive and large scale process is most likely a primary condition for the formation of exceptional Li brine-type deposits on the Argentine Puna region.

The data that we present in this contribution clearly reveal that in the Norther Puna region, the highest concentrations of Li are restricted to the Olaroz and Cauchari salt pans (Fig. 7). These two salars are located in the same tectonically N-S elongated depression. Therefore, the distinctive Li enrichment in Olaroz and Cauchari is being locally influenced by basin-scale processes, such as the characteristics and density (in terms of the quantity of springs that exist in the basin) of geothermal fields, the weathering of Li-rich lithologies, and/or geochemical processes taking place within the salars. An additional local driving factor on increasing the Li grade in the Olaroz and Cauchari's brines should likely be associated to the role of major thrusts on transporting fluids from the deepest zones of the upper crust and generating large ionic remobilizations. For example, Franco et al. (2016) reported the presence of thermal springs discharging at the location of the basin bounding structures along the marginal zones of the Salar de Olaroz. Additionally, the basin involves several hydrothermal fields directly associated with volcanic centers (Peralta Arnold et al. 2016). Therefore, hydrothermal springs in the Salar de Olaroz and Cauchari are likely related to the presence of volcanic centers, which include isolated edifices along oblique volcanic belts (e.g., Presta and Caffe 2014; Maro et al. 2016) and large volcanic complex calderas (Seggiaro 1994; Seggiaro 2013).

The lower Li grade in brines from the Salinas Grandes relative to Olaroz and Cauchari could be associated with several characteristics of the basin: 1) the catchment lithology is dominated by the Eastern Cordillera basement, which is different from that of the Northern Puna, and would, therefore, have a different geochemical signature; 2) the lack of large hydrothermal fields and volcanic rock outcrops; and 3) the less arid conditions in the basin's catchments located at the easternmost edge of the Norther Puna region. Consequently, even if the hydrothermal activity - which represents just one of the multiple expressions related to the intrinsic nature of the plateau - is considered as a major source for Li supply, additional geological, climatic, and geochemical aspects locally generating distinctive Li grades and brine compositions in every salt pan and/or basin should also be considered.

In order to compare the relative abundance of ionic species in different salars, or between samples from the same salar with uneven salinities, it is necessary to remove the effect of the evaporative concentration. The relative abundance of $\mathrm{Ca}^{2+}, \mathrm{Mg}^{2+}, \mathrm{K}^{+}, \mathrm{Li}^{+}$and $\mathrm{BO}_{3}{ }^{3-}$ in salars from the Northern Puna is presented in Figure 9. In this diagram, the evaporative effect was removed by employing TDS (total dissolved solids, for TDS method see caption of Fig. 9) normalized values. This diagram is substantially different from Figure 5 where plotted data 
involve absolute ionic concentrations (the amount of ionic species that could be obtained from one litre of brine).

Normalized concentrations revealed that the four salars contain similar proportions of $\mathrm{Ca}^{2+}$, the Salinas Grandes brines are proportionally richer in $\mathrm{K}^{+}$and $\mathrm{BO}_{3}{ }^{3-}$, and the Salar de Cauchari contains proportionally higher $\mathrm{Li}^{+}$ concentrations than its neighbour Northern Puna salars (Fig.8). This suggests that if a brine sample from the salar de Jama (which is less saline than brines from Cauchari) is hypothetically evaporated in order to increase its salinity up to the values of Cauchari, then, one litre of the Jama brine would still have a lower Li grade than the same volume of the Cauchari brine. Consequently, the evaporative concentration process of such brines would be more efficient for Li recovering at Cauchari than Jama. This statement seems an evident mater when comparing Cauchari and Jama's brines because the mean $\mathrm{Li}^{+}$concentration of Cauchari is $860 \mathrm{mg} \mathrm{L}^{-1}$ and that of Jama is $82 \mathrm{mg} \mathrm{L}^{-1}$ (Table 2). However, the extrapolation of this rule to the other salars of the Northern Puna (Fig. 9) allows stating that the evaporative concentration process in Cauchari is more efficient than in Olaroz (even if the mean $\mathrm{Li}^{+}$concentration of the latter reaches $1,014 \mathrm{mg} \mathrm{L}^{-1}$ versus $860 \mathrm{mg} \mathrm{L}^{-1}$ of the former).

The integrated analysis of the Li-rich brine chemistry from Northern Puna provides important information to evaluate the potentially economic viability of these brines with respect to Li extraction. In addition to the Li grade of brines, the substrate porosity-permeability, the aquifer water balance, and the volume of the host aquifer (Houston et al. 2011), the magnesium content is an additional issue regarding the Li-mining process because $\mathrm{Mg}^{2+}$ causes chemical interferences in the brine purification process and limits the $\mathrm{Li}^{+}$ recovering (e.g., Crespo et al. 1987; An et al. 2012; Kesler et al. 2012; An et al. 2012). The Uyuni's brines typically have high grade $\mathrm{Mg}^{2+}$ (Ericksen et al. 1978; Risacher and Fritz 1991) while the Salar de Hombre Muerto represents the opposite situation, with low magnesium contents (Kesler et al. 2012; Godfrey et al. 2013; Table 2, Fig. 8B). The Li:Mg ratios in the Northern Puna range from 0.54 to 0.92 (Table 2), which in the regional context make them closer to Hombre Muerto than to Uyuni (Fig. 8B).

Economically viable Li-rich brines in the Central Andes contain varying amounts of the major cations and anions $\left(\mathrm{Na}^{+}, \mathrm{K}^{+}, \mathrm{Mg}^{2+}, \mathrm{Ca}^{2+}, \mathrm{Cl}^{-}, \mathrm{SO}_{4}{ }^{2-}\right.$, and $\left.\mathrm{CO}_{3}{ }^{2-}\right)$, which can form a wide range of ionic brine compositions. In general, the Northern Puna's brines contain less $\mathrm{Mg}^{2+}$ than those accumulated in Atacama and Uyuni (Fig. 8B). Nonetheless, the extremely high $\mathrm{Li}^{+}$concentration of Atacama remains the most important difference between all these salars (Table 2). An additional and substantial difference is the oversized surface of Uyuni and Atacama compared with the dimension of the Northern Puna salars. These two aspects, the $\mathrm{Li}^{+}$ concentration and the salar size, are potentially limiting the whole resources of the Northern Puna salt pans. 
However, when considering the Li grade and the Li:Mg ratio of brines, the Northern Puna salt pans are revealed as very remarkable Li prospects.

\section{Conclusion}

This study reports the results of a regional Li exploration campaign covering an area of $9,000 \mathrm{~km}^{2}$ in the Northern Puna that included the four major salars in the region. These evaporite systems represent remarkable Li prospects with mean $\mathrm{Li}^{+}$concentrations varying between 82 and $1,014 \mathrm{mg} \mathrm{L}^{-1}$, and mean $\mathrm{Li}: \mathrm{Mg}$ ratios ranging from 0.92 to 0.54 .

The major chemical composition of the studied brines is rather constant; most samples are of the $\mathrm{Na} / \mathrm{Cl}^{-}$ type with some subordinated samples with a major ionic composition of the $\mathrm{Na} / \mathrm{Cl}^{-}-\mathrm{SO}_{4}{ }^{2-}$ type, and with $\mathrm{K}>\mathrm{Mg}$. Evaporative concentration, dissolution/precipitation of halite and gypsum/anhydrite, and the precipitation of calcite/aragonite/dolomite are important processes controlling the major chemical composition of brines. Unlike major ions, the concentrations of minor elements such as $\mathrm{Mg}^{2+}, \mathrm{Li}^{+}$and $\mathrm{BO}_{3}{ }^{3-}$ do not show clear correlation with salinity, which suggest that some other factors are controlling their spatial distribution in the shallowest brines of the studied salars. The absence of a geographical/geomorphological pattern for the ionic concentrations suggests that the hydrochemistry of salars is being partially conditioned by local and regional intrinsic characteristics of each basin, as well as by regional features related to the geological/tectonic nature of the Andean Plateau. These characteristics are likely responsible for the higher Li concentrations in the N-S depression occupied by the Olaroz and Cauchari salars compared with the neighbour salars located towards the margins of the northern Puna region.

The relationship between the Li grade and brine salinity indicates that the evaporative Li recovering should be more efficient in Cauchari than in the remaining salars of the Northern Puna. Despite that the salar dimension is a factor potentially limiting the whole Li resources in the Northern Puna, especially when comparing with Atacama and Uyuni, the Li grade and the Li:Mg ratio in the Northern Puna brines are defining outstanding perspectives for the salt pans of this Andean region.

\section{ACKNOWLEDGMENTS}

This study was founded by the PRH Red 101 ANPCyT of the Argentine National Government and the National University of Jujuy. R.L. López Steinmetz thanks the grant E/B003 of the SECTER - UNJu. Other funds came from projects PIO CONICET-UNJu 14020140100010CO, and FONARSEC-FITR Industria $2013 \mathrm{~N}^{\circ}$ 
391

392

393

394

395

396

397

398

399

400

401

402

403

404

405

406

407

408

409

410

411

412

413

414

415

416

417

418

419

9 (ANPCyT). The laboratory of Aguas de los Andes S. A. provided lab facilities and the Instituto de Geología y Minería (Universidad Nacional de Jujuy) complemented field logistics. The authors thank Ing. Maria Silvina Muhana Senn and Mr. Luis Omar Villegas from the Agua de los Andes laboratory for analytical advising, and also inhabitants from the communities of the Jujuy's Puna for their hospitality. Special thanks to Captain Christian Meuric for large field logistical support.

\section{References}

Allmendinger W, Jordan E, Kay M, Isacks BL (1997) The evolution of the Altiplano-Puna plateau of the Central Andes. Annu. Rev. Earth Planet. Sci., 25, 139-174.

Alonso RN (1986) Ocurrencia, Posición Estratigráfica y Génesis de los Depósitos de Boratos de la Puna Argentina. PhD Thesis, Universidad Nacional de Salta, 196 p.

Alonso H, Risacher F (1996) Geoquímica del Salar de Atacama, Parte 1: origen de los componentes y balance salino. Revista Geológica de Chile, 23, 127-136.

Alonso R, Gutiérrez R, Viramonte J (1984) Puna Austral - Bases para el subprovincialismo geológico de la Puna Argentina. 9th Congreso Geológico Argentino, 1, 43-63.

An JW, Kang DJ, Tran KT, Kim MJ, Lim T, Tran T (2012) Recovery of lithium from Uyuni salar brine. Hydrometallurgy, 64-70, 117-118.

Arias J, Viera O (1982) Estratigrafía y tectónica de la comarca Olacapato - Tuzgle, provincias de Jujuy y Salta, República Argentina. Revista del Instituto de Ciencias Geológicas, 5, 71-86, Jujuy.

Bevacqua PSJ (1992) Geomorfología del Salar de Atacama y estratigrafía de su núcleo y delta, Segunda Región de Antofagasta, Chile. Undergraduate thesis (unpublished). Universidad Católica del Norte, Antofagasta, $284 \mathrm{p}$.

Boschetti T, Cortecci G, Barbieri M, Mussi M (2007) New and past geochemical data on fresh to brine waters of the Salar de Atacama and Andean Altiplano, northern Chile. Geofluids, 7, 33-50.

Boutt DF, Hynek SA, Munk LA, Corenthal LG (2016). Rapid recharge of fresh water to the halite-hosted brine aquifer of Salar de Atacama, Chile. Hydrological Processes, 30 (25), 4720-4740.

Campbell, MG (2009) Battery lithium could come from geothermal waters. The New Scientist, 204 (2738), 23.

Carmona V, Pueyo JJ, Taberner C, Chong, G, Thirlwall M (2000) Solute inputs in the Salar de Atacama (N. Chile). Journal of Geochemical Exploration, 69-70, 449-452. 
Clesceri LS, Greenberg AE, Eaton AD (1998) Standard Methods for the Examination of Water and Waste Water. Amer. Public. Health. Assoc., 20 $0^{\text {th }}$ Edition, USA.

COCHILCO (2013) Compilación de informes sobre mercado internacional del litio y el potencial del litio en salares del norte de Chile, http://www.cochilco.cl/estudios/info-litio.asp

Coira B, Kay S, Viramonte JG (1993) Upper Cenozoic magmatic evolution of the Argentine Puna. A model for changing subduction geometry. International Geology Review, 35, 677-720.

Coira B, Kay S, Pérez B, Woll B, Hanning M, Flores P (1999) Magmatic sources and tectonic setting of Gondwana margin Ordovician magmas, northern Puna of Argentina and Chile, in: Ramos VA, Keppie D (Eds.), Laurentia Gondwana Connections before Pangea. Geological Society of America, Special Paper $336,145-171$.

Coira B, Caffe PJ, Ramirez A, Chayle W, Diaz A, Rosas S, Perez B, Orozco O, Marinez M (2004) Hoja Geológica 2366-I/2166-III: Mina Pirquitas, Provincia de Jujuy, 1:250,000. Servicio Geológico Minero Argentino, Buenos Aires.

Corenthal LG, Boutt DF, Hynek SA, Munk LA (2016). Regional groundwater flow and accumulation of a massive evaporate deposit at the margin of the Chilean Altiplano. Geophysical Research Letters, 43 (15), 80178025.

Crespo P, Palma H, Quintanilla J, Quispe L (1987) Tratamiento químico de salmueras del Salar de Uyuni, Potosí. UMSa-ORSTOM, Informe 7.

Cristiani C, Del Moro A, Matteini M, Mazzuoli R, Omarini R (1999) The Magmatism linked to the Jurassic Cretaceous rift of NW Argentina: the Tusaquillas plutonic complex (Central Andes). 14th Congreso Geológico Argentino, 2, 190-193.

de Silva SL (1989) Altiplano-Puna volcanic complex of the central Andes. Geology 17, 1102-1106.

del Papa C, Hongn F, Powell J, Payrola P, Do Campo M, Strecker MR, Petrinovic I, Schmitt AK, Pereyra R (2013) Middle Eocene-Oligocene broken foreland evolution in the Andean Calchaquí Valley, NW Argentina: insights from stratigraphic, structural and provenance studies. Basin Research, 25, 574-593.

Ericksen GE, Chong G, Vila T (1976) Lithium resources of salars in the Central Andes. In: Vine JD (ed.), Lithium Resources and requirements by the Year 2000. Geological Survey Professional Paper, 1005, 66-74.

Ericksen GE, Salas R (1977) Geology and resources of salars in the central Andes. U.S. Geologial Survey, Open File Repository 88-210, $51 \mathrm{p}$. 
Ericksen GE, Vine JD, Ballon RA (1978) Chemical composition and distribution of lithium-rich brines in salar de Uyuni and nearby salars in southwestern Bolivia. Energy, 3 (3), 355-363.

Fornillo B, Zícari J, Slipak AM, Puente F, Argento M (2015) Geopolítica del litio: industria, ciencia y energía en Argentina. Ed. El Colectivo CLACSO, Buenos Aires, 212 p.

Franco MG, Borda L, García MG, López Steinmetz RL, Flores P, Córdoba F (2016) Geochemical and sedimentological characterization of the Salar de Olaroz, northern Argentinean Puna, Central Andes. $3^{\text {rd }}$ International Workshop on Lithium, Industrial Minerals and Energy, Jujuy, Argentina.

Garrett DE (2004) Handbook of lithium and natural calcium chloride: their deposits, processing, uses and properties. Elsevier Academic Press, 1st edition.

Godfrey LV, Chan L-H, Alonso RN, Lowenstein TK, McDonough WF, Houston J, Li J, Bobst A, Jordan TE (2013) The role of climate in the accumulation of lithium-rich brine in the Central Andes. Applied Geochemistry, 38, 92-102.

González MA, Tchilinguirian P, Pereyra F, Ramallo E (2000) Hoja geológica 2366-IV: Ciudad del Libertador General San Martín, 1:250,000. Servicio Geológico Minero Argentino, Buenos Aires.

Gruber P, Medina P (2010) Global lithium availability: a constraint for electric vehicles? Master thesis, University of Michigan, $76 \mathrm{p}$.

Hardie L, Eugster H (1970) The evolution of closed-basin brines. Fiftieth Anniversary Symposia, Mineralogy and Geochemistry of Non-Marine Evaporites. Mineralogical Society of America Special Publication, 273290.

Houston J, Butcher A, Ehren P, Evans K, Godfrey L (2011) The evaluation of brine prospects and the requirement for modifications to filing standards. Economic Geology, 106, 1225-1239.

Ide F, Kunasz IA (1989) Origin of lithium in Salar de Atacama, northern Chile, in: Ericksen GE, Cañas Pinochet MT, Reinemund JA (Eds.), Geology of the Andes and Its Relation to Hydrocarbon and Mineral Resources. Circum-Pacific Council for Energy and Mineral Resources, Earth Sciences Series, 11, 165172.

Isacks BL (1988) Uplift of the Central Andean Plateau and bending of the Bolivian Orocline. J. Geophys. Res. 93, $3211-3231$

Jordan TE, Mpodozis C, Munoz N, Blanco N, Pananont P, Gardeweg M (2007). Cenozoic subsurface stratigraphy and structure of the Salar de Atacama Basin, northern Chile. Journal of South American Earth Sciences, $23,122-146$ 
Kay SM, Coira B, Caffe PJ, Chen C-H (2010) Regional chemical diversity, crustal and mantle sources and evolution of central Andean Puna plateau ignimbrites. Journal of Volcanoligy and Geothermal Research, $198(1-2), 81-111$

Kesler SE, Gruber PW, Medina PA, Keoleian GA, Everson MP, Wallington TJ (2012) Global lithium resources: relative importance of pegmatites, brine and other deposits. Ore Geology Revue, 48, 55-69.

King M (2010) Amended inferred resource estimation of lithium and potassium at the Cauchari and Olaroz salars Jujuy province, Argentina. Technical report, Groundwater Insight, Inc.

Kirschbaum A, Hongn F, Menegatti N (2006) The Cobres Plutonic Complex, eastern Puna (NW Argentina): Petrological and structural constrains for Lower Paleozoic magmatism. Journal of South American Earth Sciences, 21, 252-266.

Ide F, Kunasz IA (1989) Origin of lithium in Salar de Atacama, northern Chile, in: Ericken, GE, Cañas Pinochet MT, Reinemund JA (Eds.), Geology of the Andes and its relation to hydrocarbon and mineral resources. Circum-Pacific Council for Energy and Mineral Resources Earth Science Series, 11, 165-172.

Kunasz IA (2006) Lithium resources. In Industrial minerals and rocks, commodities, markets and uses. 7th edition. López Steinmetz RL (2017) Lithium- and boron-bearing brines in the Central Andes: exploring hydrofacies on the eastern Puna plateau between $23^{\circ}$ and $23^{\circ} 30^{\prime}$ S. Mineralium Deposita, 52, 35-50.

Lowenstein T, Risacher F (2009) Closed basin brine evolution and the influence of $\mathrm{Ca}-\mathrm{Cl}$ inflow waters. Death Valley and Bristol Dry Lake, California, QaidamBasin, China, and Salar de Atacama, Chile. Aquatic Geochemistry, 15, 71-94.

Lupo L, Morales M, Maldonado A, Grosjean M (2006) A high-resolution pollen and diatom record from Laguna Los Pululos $\left(22^{\circ} 36^{\prime} \mathrm{S} / 66^{\circ} 44^{\prime} \mathrm{W} / 4500 \mathrm{~m}\right.$ asl), NW Argentinean Puna, since $c a .800$ AD. Reconstructing Past Regional Climate Variations in South America over the Late Holocene: A New PAGES Initiative. International Symposium, Malargüe, Argentina, 24.

Maro G, Caffe PJ (2016) The Cerro Bitiche Andesitic Field: pretological diversity and implications for magmatic evolution of mafic centers from the northern Puna. Bulletin of Volcanology, 78-51, doi: 10.1007/s00445016-1039-y

Maro G, Caffe PJ Jofré C (2016) Xenolitos ultramáficos en andesitas máficas neógenas de la Puna Norte. Revista de la Asociación Geológica Argentina, 73, in press. 
McGlue MM, Ellis G, Cohen A, Swarzenski P (2012) Playalake sedimentation and organic matter accumulation in an Andean piggyback basin: the recent record from the Cuenca de Pozuelos, NW Argentina. Sedimentology, 59,1237-1256.

McQuarrie N, Horton BK, Zandt G, Beck S, DeCelles PG (2002) Lithospheric evolution of the Andean fold-thrust belt, Bolivia, and the origin of the central Andean plateau. Tectonophysics 399 (1e4), $15 \mathrm{e} 37$. http://dx.doi.org/10.1016/j.tecto.2004.12.013.

Méndez V, Navarini A, Plaza D, Viera O (1973) Faja Eruptiva de la Puna oriental. 5th Congreso Geológico Argentino, 4, 89-100.

Mohr S, Mudd G, Giurco D (2010) Lithium Resources and Production: a critical global assessment. Prepared for CSIRO Minerals Down Under Flagship, by the Institute for Sustainable Futures, University of Technology, Sydney, and Department of Civil Engineering, Monash University, Final Report, 107 p.

Moraga A, Chong G, Fortt MA, Henríquez H (1974) Estudio geológico del Salar de Atacama. Provincia de Antofagasta. Boletín del Instituto de Investigaciones Geológicas, 29, Santiago, Chile, 56 p.

Munk LA, Hynek SA, Bradley D, Boutt D, Labay K, Jochens H (2016) Lithium brines: A Global Perspective. Reviews in Economic Geology, 18, 339-365.

Orberger B, Rojas W, Millot R, Flehoc C (2015) Stable isotopes (Li, O, H) combined with chemistry: powerful tracers for Li origins in Salar deposits from the Puna region, Argentina. Procedia Earth and Planetary Science, 13, 307-311.

Peralta Arnold YJ, Cabssi J, Tassi F, Caffe JP, Vaselli O (2017). Fluid geochemistry of a deep-seated geothermal resource in the Puna plateau (Jujuy Province, Argentina). Journal of Volcanology and Geothermal Research, doi: 10.1016/j.jvolgeores.2017.03.030.

Peralta Arnold YJ, Tassi F, Caffe PJ (2016) Hydrothermal systems and lithium deposits. Northern Puna, Jujuy Argentina. $3^{\text {rd }}$ International Workshop on Lithium, Industrial Minerals and Energy, Jujuy, Argentina.

Perkins JP, Ward KM, de Silva SL, Zandt G, Beck SL, Finnegan NJ (2016) Surface uplift in the Central Andes driven by growth of the Altiplano Puna Magma Body. Nature Communications, doi: $10.1038 /$ ncomms 13185

Presta JF, Caffe PJ (2014) Historia eruptiva de los volcanes monogenéticos de El Toro $\left(23^{\circ} 05^{\prime} \mathrm{S}-66^{\circ} 42^{\prime} \mathrm{O}\right)$, Puna norte, Argentina. Andean Geology 41:142-173

Rettig SL, Jones BF, Risacher F (1980) Geochemical evolution of brines in the Salar de Uyuni, Bolivia. Chemical Geology, 30, 57-79. 
537

541

Risacher F, Fritz B (1991) Quaternary geochemical evolution of the Salar of Uyuni and Coipasa, Central Altiplano, Bolivia. Chemical Geology, 90, 211-231.

Risacher F, Fritz B (2009) Origin of salt and brine evolution of Bolivian and Chilean Salars. Aquat. Geochemistry, $15,123-157$.

Risacher F, Alonso H, Salazar C (1999) Geoquímica de aguas en cuencas cerradas: I, II y III Regiones - Chile. Convenio de Cooperación ORSTOM - DGA - UCN - IRD, SIT 51, Santiago de Chile, 781 p.

Risacher F, Alonso H, Salazar C (2003) The origin of brines and salts in Chilean Salars: a hydrochemical review. Earth Sciences Revue, 63, 249-292.

Seggiaro RE (1994) Petrología, geoquímica y mecanismos de erupción del complejo volcánico Coranzulí. Ph.D. thesis, Universidad Nacional de Salta.

Seggiaro RE (2013) Hoja geológica 2366-III: Susques, 1:250,000. Servicio Geológico Minero Argentino, Buenos Aires.

Schmidt N (2010) Hydrological and hydrochemical investigations at the Salar de Uyuni (Bolivia) with regard to the extraction of lithium. FOG, 26.

Schwab K (1973) Die Stratigraphie in der umgebung des salar Cauchari. Geotekt. Forsch., Germany, 43, 168 p.

Schwab K, Lippolt H (1974) K-Ar mineral ages and Late Cenozoic history of the Salar de Cauchari area (Argentine Puna). International Association of Volcanic Chemistry, Earth’s Interior Symposium, Andean and Antartic Volcanological Problems, Chile, 698-714.

Shcherbakov AV, Dvorov VI (1970) Thermal waters as a source for extraction of chemicals. Geothermics 2 (2), $1636-1639$.

Stoertz GE, Ericksen GE (1974) Geology of salars in northern chile. Geological Survey professional paper 811, 65 p.

Turner JC (1959) Estratigrafía del Cordón de Escaya y la Sierra de Rinconada, Jujuy. Revista de la Asociación Geológica Argentina, 15 (1), 15-39.

Turner JC (1960a) Estratigrafía de la Sierra de Santa Victoria y adyacencias. Boletín de la Academia Nacional de Ciencias, 41 (2), 163-169, Córdoba.

Turner JC (1960b) Estratigrafía del Nevado de Cachi y sector al oeste (Salta). Acta Geológica Lilloana, 3, 191226.

Turner JC (1972) Puna. Geología Regional Argentina, 1, 13-56. Buenos Aires. 
Warren JK (2010) Evaporites through time: Tectonic, climatic and eustatic controls in marine and nonmarine deposits. Earth Sciences Reviews, 98 (3), 217-268.

Williams LB, Hervig RL (2002) Exploring intracrystalline boron isotope variations in mixed-layer illite/smectite. Am. Miner. 87.

Witherow RA, Lyons WB (2011) The fate of minor alkali elements in the chemical evolution of salt lakes. Saline Systems, 7 (2), 2-14.

Yaksic A, Tilton JE (2009) Using the cumulative availability curve to assess the threat of mineral depletion: The case of lithium. Resources Policy, 34, 185-194.

Zhang L, Chan LH, Gieskes JM (1998) Lithium isotope geochemistry of pore waters, Ocean Drilling Program Sites 918 and 919, Irminger Basin. Geochim. Cosmochim. Acta, 62.

Zappettini E (1989) Geología y metalogénesis de la región comprendida entre las localidades de Santa Ana y Cobres, Provincias de Jujuy y Salta. República Argentina. Ph.D. thesis, Universidad de Buenos Aires, 189 p.

\section{Figure captions}

Fig.1. Map of the Andean Plateau (dark green area), showing the location of the Salar de Atacama, Uyuni and Hombre Muerto (white areas). Thick dashed grey lines indicate the internal Plateau boundaries between the Bolivian Altiplano, the Argentinean Northern and Southern Puna (Alonso et al. 1984). There are many other salars in the Chilean Desierto de Atacama, in the Bolivian Altiplano and in the Argentinean Puna Plateau that are not shown in this map.

Fig. 2. Simplified geologic map of the Northern Puna Plateau between $23^{\circ} 06^{\prime} \mathrm{S}$ and $23^{\circ} 56^{\prime} \mathrm{S}$, modified from González et al. (2000), Coira et al. (2004), and Seggiaro (2013). The map shows the location of the Northern Puna's salars. A-A' is the altitudinal transect of the Northern Puna Plateau at $23^{\circ} 30^{\prime}$ 'S. Lithological legend: 1) modern salar; 2) Quaternary alluvial deposits, including piedmonts, alluvial fans and alluvial plains; 3) sedimentary units including the Cretaceous-Paleocene rift related and the Upper Eocene to Upper Miocene synorogenic deposits; 4) Plio-Pleistocene ignimbrite; 5) Miocene-Pliocene ignimbrite; 6) Miocene dacite; 7) Jurassic-Cretaceous granite; 8) Ordovician granite; 9) Ordovician metasedimentary basement of the Northern 
Fig. 7. Li grade zones in the four major salars of the Northern Puna Plateau. Brine Li concentrations are in mg L-

Fig. 4. Ternary diagrams showing the relative ionic concentrations of brines from the Salar de Jama (JA), Olaroz (OL), Cauchari (CA) and Salinas Grandes (SG). Ionic concentrations are expressed in meq $\mathrm{L}^{-1}$.

Fig. 5. Comparative concentrations of $\mathrm{Ca}^{2+}, \mathrm{Mg}^{2+}, \mathrm{K}^{+}, \mathrm{Li}^{+}$and $\mathrm{BO}_{3}{ }^{3-}$ (A) and electrical conductivity (B) of samples collected from the Salar de Jama (JA), Olaroz (OL), Cauchari (CA) and Salinas Grandes (SG).

Fig. 6. Scatter diagrams showing the variation of $\mathrm{Na}^{+}$versus $\mathrm{Cl}^{-}(\mathrm{A})$ and $\mathrm{Ca}^{2+}$ versus $\mathrm{SO}_{4}{ }^{2+}$ (B and $\mathrm{C}$ ) in the studied brines. Abbreviations are: Jama (JA), Olaroz (OL), Cauchari (CA), Salinas Grandes (SG), Guayatayoc (G), Hombre Muerto (HM), Uyuni (UYU) and Atacama (ATA). The HM data were taken from Godfrey et al. (2013). The UYU samples UB and UE and the ATA data set are from Risacher and Fritz (2009). The UYU samples 109, 128 and 120 were taken from Ericksen et al. (1977). The G samples are from Lopez Steinmetz (2017) and samples JA, OL, CA and SG are from this contribution. The HM samples 10, 11 and 12 are lagoon brines, sample 13 is a brine collected at $200 \mathrm{~cm}$ depth in a hole drilled into the salar (Godfrey et al. 2013). The UYU samples UB and UE correspond to brines collected at $100 \mathrm{~cm}$ depth (Risacher and Fritz 2009), sample 109 was collected in a brine pool and samples 120 and 128 are brines collected from holes drilled 40 to $50 \mathrm{~cm}$ into the salt crust (Ericksen et al. 1977). Samples $\mathrm{GG}_{3}, \mathrm{GG}_{4}$ and $\mathrm{GQ}_{0}$ were collected from pits dug in the playa lake sediments (Lopez Steinmetz 2017).

\section{1.}

623

624 Fig. 8. Scatter diagrams showing the variation of $\left(\mathrm{Na}^{+}+\mathrm{Cl}^{-}\right)$and Conductivity with $\mathrm{Li}^{+}$(A) and $\mathrm{Li}^{+}$versus $\mathrm{Mg}^{2+}$ 625 (B and C) in the studied brines. Jama (JA), Olaroz (OL), Cauchari (CA), Salinas Grandes (SG). Data 
corresponding to Guayatayoc (G), Hombre Muerto (HM), Uyuni (UYU) and Atacama (ATA) are plotted for comparison. Details concerning the HM, UYU, ATA and G plotted data are presented in caption of Fig. 6.

Fig. 9. Comparative $\mathrm{Ca}^{2+}, \mathrm{Mg}^{2+}, \mathrm{K}^{+}, \mathrm{Li}^{+}$and $\mathrm{BO}_{3}{ }^{3-}$ concentration ranges of samples collected from the Salar de Jama (JA), Olaroz (OL), Cauchari (CA) and Salinas Grandes (SG). The TDS value was obtained from electrical conductivity, by employing a conversion factor of 1 (TDS = Conductivity) based on the relation between the concentration of all the analysed ions relative to conductivity (Fig. A of the electronic supplementary material).

Table 1. Chemical composition of brines samples collected in the Salar de Jama (JA), Olaroz (OL), Cauchari (CA) and Salinas Grandes (SG).

Table 2. Comparative attributes of the Northern Puna's salars and Atacama, Uyuni and Hombre Muerto. The mean $\mathrm{Li}^{+}$concentration and $\mathrm{Li}: \mathrm{Mg}$ ratios of Jama, Olaroz, Cauchari and Salinas Grandes were settled based on original data from this contribution (Table 1). The mean $\mathrm{Li}^{+}$concentration and $\mathrm{Li}: \mathrm{Mg}$ of Guayatayoc correspond to the mean value of the 3 brine samples (samples G3, G4 and Q0) reported in Lopez Steinmetz (2017). The mean $\mathrm{Li}^{+}$concentration reported for Atacama are from Ide and Kunasz (1989) and Kunasz (2006), and the mean $\mathrm{Li}: \mathrm{Mg}$ corresponds to values reported by COCHILCO (2013). The mean $\mathrm{Li}^{+}{ }^{+}$concentration and $\mathrm{Li}_{\mathrm{Mg}} \mathrm{Mg}^{\mathrm{a}}$ ratio in Uyuni corresponds to the mean values of 38 samples (from sample 100 to sample 133 and samples 146,147 and 147A) reported by Ericksen et al. (1977). The mean $\mathrm{Li}^{+}{ }^{\mathrm{b}}$ concentration and $\mathrm{Li}: \mathrm{Mg}{ }^{\mathrm{b}}$ ratio corresponds to the mean values of the 164 samples (from sample UA to sample RZ) reported by Risacher and Fritz (1991). The mean $\mathrm{Li}^{+}$c concentration and $\mathrm{Li}: \mathrm{Mg}$ ratio of Hombre Muerto correspond to the mean value of the 9 samples (samples 4, 5, 6 and 9 to 14) reported by Godfrey et al. (2013). The mean $\mathrm{Li}^{+\mathrm{d}}$ concentration in Hombre Muerto corresponds to the mean $\mathrm{Li}^{+}$concentration of $100 \mathrm{~cm}$-deep brines reported by Garrett (2004) and Kesler et al. (2012). 